\title{
Sustainable Development through Science and Technology
}

\section{Tariq Husain}

"Science education, in the broad sense... is a fundamental pre-requisite for democracy and for ensuring sustainable development."

Declaration on Science and the Use of Scientific Knowledge, World Conference on Science, Budapest, July 2, 1999

\begin{abstract}
After 50 years of nationhood, about 60 million Pakistani citizens still live in absolute poverty which is a condition so debasing that it robs the poor of the very potential of their genes. Illiteracy, malnutrition, high maternal, child and infant mortality afflict more than 50\% of Pakistan's population of 144 million. Due to mismanagement of its human and natural resources Pakistan is in a vicious cycle of economic dependence (Figures 2 \& 3) with high indebtedness, low growth rates of exports and GDP and a decaying education system. During the last two decades Pakistan has engaged in firefighting through external debt re-schedulings and increasing its dependence on the Bretton Woods institutions (World Bank, International Monetary Fund) and their richer shareholders. As a result the important development needs of the nation's human capital have been grossly neglected. It has failed to develop its human capital, particularly its domestic scientific and engineering communities and thus is not ready to meet the growth challenges of the $21^{\text {st }}$ century. It is postulated that Pakistan must, on a crash basis, develop a domestic scientific and technology (S\&T) community and create a scientific infrastructure if it seeks to become economically and politically self-reliant. With about 100 scientists/engineers for a million population, Pakistan's current S\&T capacity is woefully inadequate to be able to capitalise on the wealth of opportunities that are becoming available through globalisation. The S\&T capacities of Pakistan's competitors in the world marketplace are significantly higher $(300$ per million for India; 600 per million for China; 2,600 per million for Korea). Pakistan needs both enhanced S\&T capacity and the associated education system if it is to increase the "science-cum-knowledge content" of its exports and GDP. This is a sine qua non for achieving expanded economic well
\end{abstract}

\footnotetext{
* Advisor, Center for Research on Poverty Reduction and Income Distribution, Planning Commission, Pakistan
} 
being for its citizens and providing the wherewithal for ensuring their security from internal and external threats. Not doing so will leave Pakistan at the bottom of the country league table in terms of poverty, security and even liberty. This is a future that Pakistan should not have.

\section{Sustainable Development through Science and Technology}

\section{Context and Issues}

In 1930, when industrial economies started descending into the Great Depression, John Maynard Keynes reminded his anxious contemporaries to consider

"the economic possibilities of our grandchildren. (Scientific accomplishments, i.e.) Coal, steam, electricity, petrol, steel, rubber, cotton, the chemical industries, automatic machinery, mass production, wireless, printing have brought in sight the possibility that, assuming no major war and no important increase in population, the economic problem may be solved within a hundred years. This means that the economic problem is not the permanent problem of the human race."

Keynes defined the economic problem as

"the struggle for subsistence, always hitherto the primary, most pressing problem of the human race - not only of the human race, but of the whole biological kingdom from the beginnings of life in its most primitive forms..."

Seventy years later, the economic problem has been solved for most of the citizens of OECD countries; but for the developing world there is no end in sight. Certainly, this is the case for Pakistan with 60 million of its citizens living in daily contact with Lord Keynes' economic problem, i.e. living in absolute poverty. Twenty five years ago, Robert McNamara, former President of the World Bank, defined "absolute poverty" as:

“... a condition of life so limited by illiteracy, malnutrition, disease, high infant mortality and low life expectancy as to be beneath any rational definition of decency."

\footnotetext{
${ }^{1}$ From Piel, Gerard, The Age of Science, 2001, p. 432.

${ }^{2}$ Ibid, p. 381.

${ }^{3}$ Speech to the Board of Governors, 1973.
} 
Most of us who have adequate food, shelter and the possibility of a better future cannot imagine the hopelessness, vulnerability and voicelessness of those of our fellow citizens who live in absolute poverty. This must not be, as it has been, the permanent problem of Pakistan.

At the beginning of this millennium Pakistan stands at a crossroad. This is not the first time that the Pakistani nation has faced stark choices. In its 50 plus years of existence the country has experienced a range of governments - from parliamentary democracy in the early part of the 1950s through a series of military governments till the recent (fourth) peaceful takeover by the military. In between, there have been five short spells of "technical" democracy; that is, democracy in form, but authoritarianism in substance. This was true for the first civilian administration of Zulfiqar Ali Bhutto in the early 1970s. And this was true of the subsequent four civilian administrations in the 1990s of Benazir Bhutto and Mian Nawaz Sharif. These facts and this context are important as we examine the stark choices for the country at the beginning of the millennium. After about half a century of existence, Pakistan's per capita income is US\$460. Most OECD households spend that much money on coffee in less than a year. Out of a population of 144 million, $50 \%$ do not have access to safe water; $80 \%$ do not have access to sanitation; $55 \%$ are illiterate; 10 million children under five are malnourished; and, as noted above, $40 \%$ are living in absolute poverty. Only $3 \%$ of the relevant age group participates in university level education versus more than $40 \%$ for most OECD countries. The "left out human capital" at all levels of the education pyramid is (almost) sinfully high. (Figure 1) 
Figure 1: Pakistan - Basic Characteristics

\begin{tabular}{llll}
\hline Total Population (2002) & 144 million & & \\
Age Structure (2002) & $<15 \mathrm{yrs}$ & $42.87 \%$ & 61.7 million \\
& $15-64 \mathrm{yrs}$ & $52.89 \%$ & 76.2 million \\
& $>65 \mathrm{yrs}$ & $4.24 \%$ & 6.1 million
\end{tabular}

Income distribution: Ratio $\quad 27.6 / 4.1=7$

of highest to lowest deciles

Literacy Rate (over 10 yrs) $\quad$ 46\% (M: 61\%; F:39\%)

\section{Education Pyramid}

\begin{tabular}{lcc} 
& $\begin{array}{l}\text { Enrollment } \\
\text { Rate (\%) }\end{array}$ & $\begin{array}{c}\text { Left out Human } \\
\text { Potential }\end{array}$ \\
\cline { 2 - 3 } Primary (5-9 yrs age) & 75 & 25 \\
Middle (10-12) & 46 & 54 \\
Lower Secondary (13-14) & 31 & 69 \\
Higher Secondary (15-16) & 11 & 89 \\
College \& University level (17-23) & 3 & 97
\end{tabular}

University level enrollment per 100 of population

$\begin{array}{ll}\text { Pakistan } & 0.359 \\ \text { India } & 0.642 \\ \text { Iran } & 1.600 \\ \text { Korea } & 5.609 \\ \text { China } & 0.473 \\ \text { Sri Lanka } & 0.474 \\ \text { Japan } & 3.14\end{array}$

Sources: Education for All, 1998 Census. Government of Pakistan World Development Reports (World Bank) 
Pakistan's economic problems have grown instead of becoming less onerous. Mostly because of the under-investment in human capital (the "left out" in the education pyramid in Figure 1), we have not been able to manage our economic issues well, and so today, Pakistan is in a debt-trap with its total debt approaching $90 \%$ of GDP. India's total debt, by comparison, is less than $50 \%$ of GDP, as is the case with all East Asian countries. The debt-service has lately been between 5 and $6 \%$ of GDP and more than $25 \%$ of exports. This debt burden is high on a relative as well as on an absolute international scale. Debt rescheduling with the Paris and London clubs has postponed the debt service burden from 1999/2000 to a medium term future. But with export earnings growing at an anemic 3\% per year (1990-1998) the critical issue facing the government is how to create earned foreign exchange to finance this debt service when it does fall due in the medium term. The only sustainable policy is to expand export earnings to a multiple of the recent rate. Export earning growth rates of China, Korea, India, and Malaysia have been in excess of $13 \%$ per year for the same period. These higher growth rates of export earnings for these countries are primarily due to the higher proportions of high technology ${ }^{4}$ content in their exports. For China, India, Indonesia, Korea and Malaysia, the proportion of high technology exports as a percentage of manufacturing exports has been $21 \%, 11 \%, 20 \%, 39 \%$ and $67 \%$ respectively. For Pakistan, this proportion is less than 5\%: its principal exports are primary commodities, textiles, leather products, surgical instruments and sporting goods. Pakistan's export earnings (or GDP) are unlikely to increase at the needed rates unless it creates the human resource capacity to increase the science-content of its production and exports. This would require a herculean effort by Pakistan to upgrade and reform its education system, particularly its domestic science and engineering capabilities. Pakistan also has to provide gainful employment to a labour force which is growing in excess of $3 \%$ per year. Its current labour force is about 55 million, but given its "young" age structure ( $42 \%$ of its population is below age 15$)$, its labour force will more than double in 15 years with substantial increases every year. Meeting their education, health, housing and then their employment needs is a known claim on future income. Without higher rates of growth in GDP and exports, more and more Pakistani citizens will be experiencing absolute poverty.

So, besides the shorter term "firefighting" of debt rescheduling, the government must focus on the medium-to-long term development needs of the nation. This will require a shift of priorities and higher level governmental attention to: a) expanding export earnings by increasing the

\footnotetext{
${ }^{4}$ Computers, drugs, medicines, electronics, automobiles, chemicals and machinery.
} 
"science-content" of its products significantly, and b) expanding domestic employment opportunities for the current unemployed as well as the anticipated 60 million entrants to the labour force during the next decade and a half and beyond. Accomplishing these objectives will require significant increases in Pakistan's total factor productivity by a combination of policies and investments which both improve human capital (education, gainful employment) and promote an environment where innovation is encouraged. The most imperative necessity (and there are no equally efficient alternatives either) is to improve the absorption capacity of the Pakistani domestic scientific and engineering community to enable it to work with Pakistan's farmers, industrialists, and service providers to improve the science/knowledge-content of Pakistani products. And also to enable this community to borrow from international R\&D as well as to create its own solutions to Pakistan's local developmental problems. If Pakistani society is to become economically (and politically) self-reliant, it is essential that the problems of its national security, agriculture, of its local pests and diseases, of its local material base, of its environment, water bodies, soil mass, salt balance, watershed erosion, energy production, industrial production be solved by domestic talent. This will not be possible without effective as well as significant upgrading of its human (particularly scientific) resource base. Creative problem solving by this upgraded human resource base is the key to solving the economic problem, i.e. sustainable socio-economic development.

Pakistan's short term degrees of freedom are limited - it is dependent on non-citizens for resources, yet it has to compete with countries which have had significant head starts. It has to get out of these vicious circles while negotiating these short term constraints (Figures 2\&3). In an inter-dependent, globalising world, the socio-economic problems of Pakistan are interlinked scientifically, economically and politically with those of its competitors in the market place. Scientifically, their resolution requires an understanding of the physical, chemical and biological processes and the interaction of these processes in the entire earth system. Politically and economically, policy options to address these problems converge on the need for internationally accepted actions relating to energy, technology, environmental standards, labour standards and international trade. These issues are large and are stretching world political leadership to breaking point. National actions and international cooperative action are needed to address these trans-boundary problems. Pakistan does not have the human talent to diagnose, anticipate, solve these complex issues; nor to negotiate satisfactory solutions with either bilateral or multi-lateral (IMF, IBRD, WTO) partners. 
Figure 2: The Vicious Circle of Technological Dependence Adapted from "Essays in Science" by Dr. M.A. Kazi

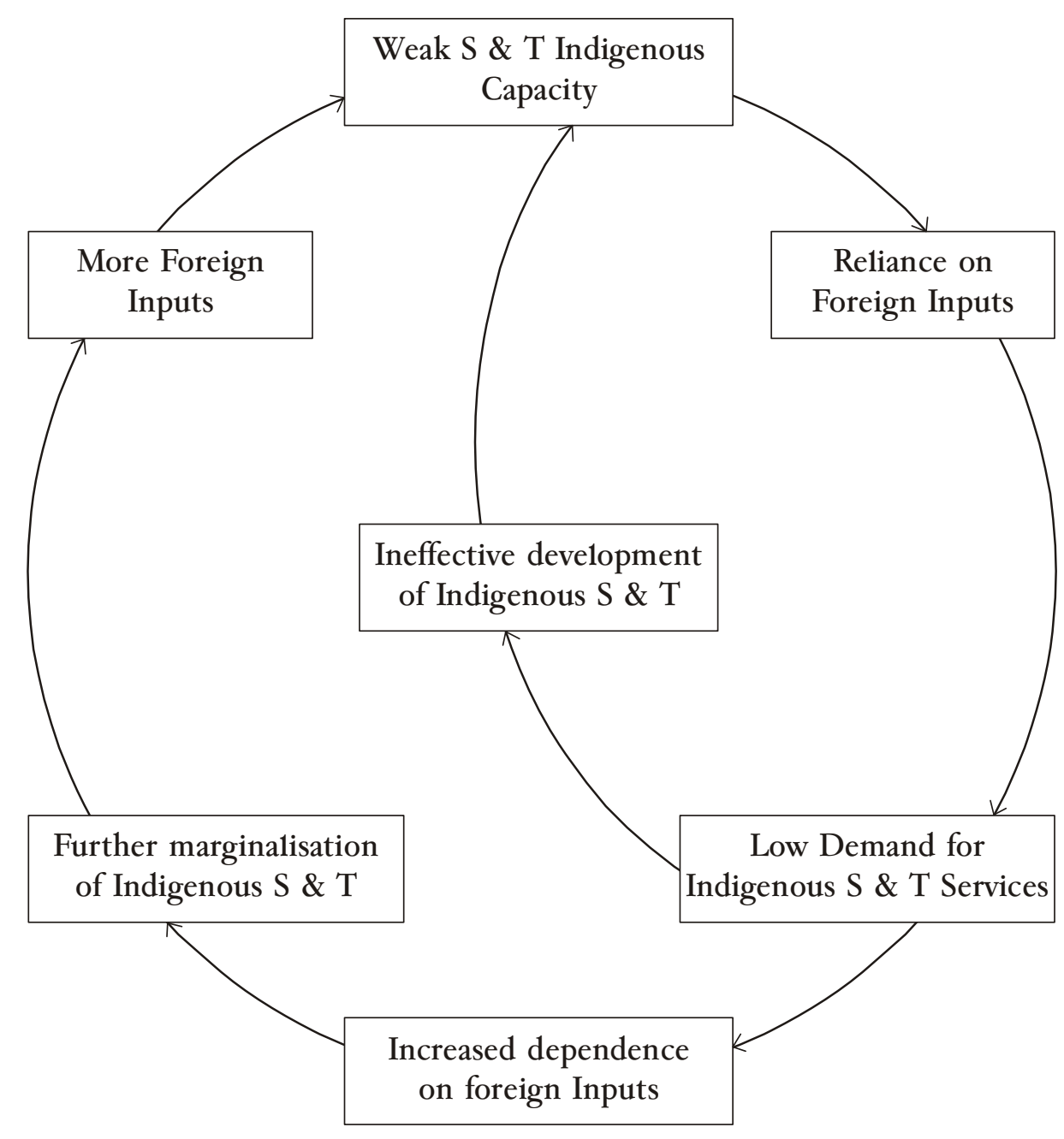


Figure 3: The Vicious Circle of Economic Dependence Superimposed on the Circle of Technological Development

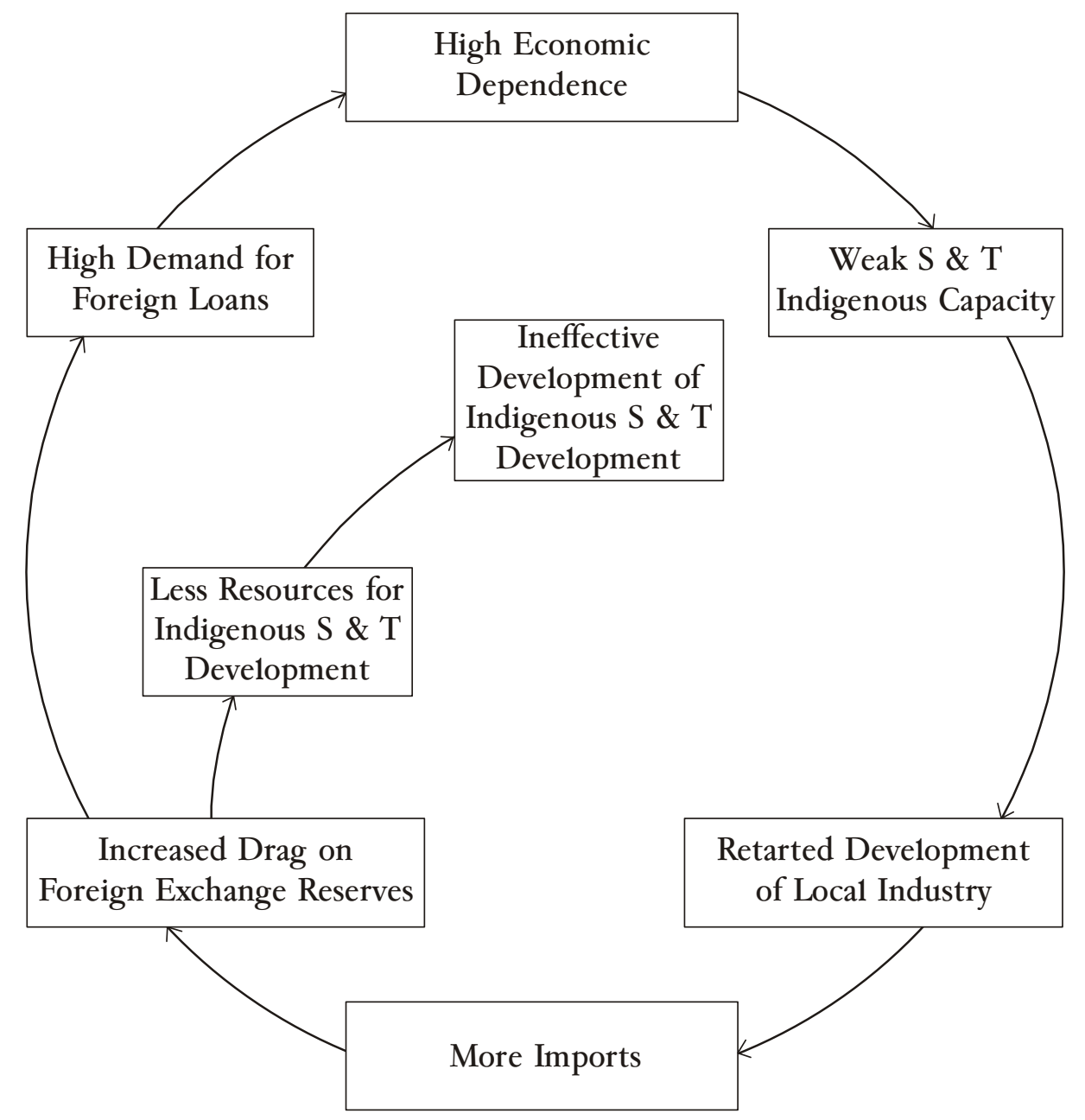

In this context, my submission is that the consequences of globalisation for Pakistan need different and non-marginal solutions and thus require more effective attention by the government and Pakistan's intellectuals. As noted above, Pakistan cannot carry on as it has so far done - i.e. be reactive and pre-occupied with short term firefighting - a behaviour partly because we as a nation, seem to be incapacitated by the weight of debt and poverty. But it is mostly due to our limited domestic buman (particularly scientific) capacity, which is, and has been, grossly inadequate for the challenges of sustainability. To concretise the magnitude of Pakistan's socio-economic challenges, let me give some highlights: 
- The annual environmental cost from air and water pollution, and land degradation exceeds US\$2.2 billion. This is about $4 \%$ of Pakistan's GDP. The people impact is in tens of million. (see Figure 4)

Figure 4: Annual Cost /1 of Environmental Mis-management

\begin{tabular}{|c|c|c|c|c|}
\hline \multirow[t]{2}{*}{$\begin{array}{c}\text { Environmental } \\
\text { Issue }\end{array}$} & \multicolumn{2}{|c|}{$\begin{array}{l}\text { Estimated Annual Cost to the } \\
\text { Economy (1990s) US\$ } \\
\text { millions }\end{array}$} & \multicolumn{2}{|c|}{$\begin{array}{l}\text { People Impact } \\
\text { (Millions) }\end{array}$} \\
\hline & Pakistan & India & Pakistan & India \\
\hline $\begin{array}{l}\text { Air Pollution } \\
\text { Surface water }\end{array}$ & $900 / 2$ & 1500 & $30+$ & 50 \\
\hline pollution & 750 & 6000 & $50+$ & $100+$ \\
\hline $\begin{array}{l}\text { Groundwater } \\
\text { pollution }\end{array}$ & $\begin{array}{c}\text { Aquifer } \\
\text { Destruction } \\
\text { (salt:chemicals) }\end{array}$ & unknown & $40+$ & \\
\hline Soil degradation & 350 & 2000 & $\begin{array}{c}\text { most arable } \\
\text { land }\end{array}$ & $\begin{array}{c}0 \% \text { of arable } \\
\text { land }\end{array}$ \\
\hline $\begin{array}{l}\text { Rangeland } \\
\text { degradation }\end{array}$ & 130 & & & loss of \\
\hline $\begin{array}{l}\text { Deforestation } \\
\text { Industrial }\end{array}$ & 50 & 200 & & ecological \\
\hline $\begin{array}{l}\text { hazardous waste } \\
\text { Loss of biodiversity }\end{array}$ & $\begin{array}{l}\text { unknown } \\
\text { unknown }\end{array}$ & $\begin{array}{l}\text { unknown } \\
\text { unknown }\end{array}$ & & functions \\
\hline
\end{tabular}

Source: World Bank

- Poverty and associated human deprivation resulting from the above referred mismanagement of our natural resources (Figure 4) affects at least $50 \%$ of the country's population. The biggest deprivation is of course, illiteracy, which afflicts $\mathbf{8 0}$ million people and closes many options for them. It also reduces their productivity and so close to 60 million, $40 \%$ of the total, live in absolute poverty, a condition in which even food needs are not satisfied and vulnerability to shocks is high.

- Inequality of income is high. The ratio between the income shares of the top and bottom deciles is seven. In a comparison with India, 
Indonesia and Bangladesh, Pakistan has the highest level of inequality.

- Pakistan also spends about 7\% of its GNP on defense. This is unsustainably high. Perhaps it is necessary in our geopolitical environment, but this bears re-examination, given our inequality and our poverty.

Salt Balance: Given the importance of the agricultural sector $(25 \%$ of GDP; $>80 \%$ of exports) it will be pertinent to specially mention two of Pakistan's most serious environmental deteriorations: salt balance in the Indus Basin, and watershed erosion in the catchment areas of our river systems. Together these two are destroying our most precious resource, i.e. the integrated irrigation system of the Indus Basin which feeds us and provides the bulk of our export earnings. The salt balance issue springs from the relatively straightforward arithmetic that unless the outflow of salts out of the Indus Basin equals or exceeds the salts flowing into the Basin, salt accumulation would occur in the Basin. If such accumulations occur, then it is only a matter of time before salt accumulation in the soil and the underground aquifer becomes intolerable to plants and life as it is known today. The Indus Basin system is unique in that it has virtually no return flow of subsurface drainage water - effluent from canal commands remain in the canal commands ${ }^{5}$. In gross terms, about 35 million tonnes of dissolved salts enter the Indus Basin annually, about 7 million tonnes are (presently) discharged into the sea, leaving a net annual addition of 28 million tonnes to the canal commanded area. This amounts to an insignificant annual increment, but adds up to gradually toxify the aquifers and eventually will make agriculture unviable in the Indus Basin.

The salt balance arithmetic of the presently usable ground water areas deserves special mention in this context. So far, human reclamation efforts or natural processes have essentially moved soil salts from the upper soil layers to either below the root zone or into the aquifer itself. As more surface water is brought into these areas and/or ground water is recirculated without providing effective salt drainage, the soils or the aquifer continue adding to their prior accumulations of salt. This positive salt accumulation process has to be stopped or slowed down. If neither is done, these areas would eventually become saline ground water areas. So far, drainage projects (SCARPS) in usable ground water areas have only attempted to address water balance issues, i.e. lowering the water table. In

\footnotetext{
${ }^{5}$ Minor exceptions are the Swat Canals, the Right Bank Canals of Guddu and Sukkur Barrages, Khairpur Scarp, and the Chaj Saline zone scarp.
} 
the longer-term view, the salt balance issue has cardinal importance. The Left Bank outfall drain is the first effort to export salt from the basin into the sea. But it has to be used for this purpose through effective maintenance. We have just begun to scratch the surface of this environmental issue.

Watershed Erosion: In the northern catchment areas of the Indus and Jhelum, watershed erosion has been a recognised issue for quite some time, but little authoritative data is available to policy makers or even analysts on the rates of watershed erosion and their likely effects on Kharif and Rabi river flows and on the siltation of the rivers and reservoirs. Since human populations inhabit watershed areas, erosion control has a more immediate imperative - as it deals with the problem of poverty in the uplands, which is partly the result of misuse of watershed areas through over-intensive farming on steep slopes, over-grazing of range lands, and removal of forest (for wood fuel). Loss of vegetation in low rainfall hilly areas through uncontrolled grazing has not only reduced the carrying capacity of the land for livestock, but has led to loss of top soil, in some cases down to bedrock, and has increased rainfall runoff rates, aggravating flooding downstream. In many areas this process may already have gone beyond the point of reversibility.

Both salt accumulation in the Indus Basin and watershed erosion amount to a "mining" of the nation's most precious natural resource base. Preventive action is needed today. Tomorrow, it may be too late. Scientific and engineering capacity is needed to address these gigantic issues. Pakistan does not have the needed capacity in science or engineering or agricultural science (soil physics and chemistry).

\section{Scientists and Societal Problems}

The $20^{\text {th }}$ century witnessed a colossal change in the way society honoured its scientists. During World War I scientists served as ordinary soldiers who were conscripted and fought on the frontlines. During World War II, however, they were treated as irreplaceable national assets and were kept at home to provide the intellectual muscle for the war effort. Bertrand Russell described it eloquently when he said that till the early $20^{\text {th }}$ century, when fighting wars nations honoured their military generals, but during the $2^{\text {nd }}$ World War (particularly after the Manhattan project) nations fought for their nuclear physicists. The reason for this significant change in the relative importance of scientists was the demonstration of the significant enhancement of national security that was achieved by the application of science to complex military problems. The invention of radar enabled 
Britain to gain air superiority over Germany. The defection of German and Italian scientists to the US enabled the US to build the atomic bomb before Germany or Russia. The application of probability theory improved air bombing effectiveness and the search for submarines lost at sea. These kinds of applications of science, mathematics and probability theory gave comparative military advantage to nations on a scale not observed before in human history.

A new discipline - Operations Research - was created during the $2^{\text {nd }}$ World War to apply physics, mathematics and probability theory to solve optimisation, scheduling, search, inventory management and transport management problems. This began with military applications but, in the 1950 s, began to be applied to problems of industry, medicine and agriculture. The $2^{\text {nd }}$ World War was won by scientists and engineers. Both the laboratory and the factory provided the new arsenal for democracy: radar, missiles, penicillin, atomic bomb - all were harvested from the knowledge and innovativeness of an elite group of scientists and engineers. Pakistan's own Nuclear Programme is a testimony to how scientists of Pakistan have given it a military deterrent capacity which is vital for national security. During the 1940s, the US national war effort was coordinated by Dr. Vannevar Bush who headed the Office of Scientific Research and Development (OSRD) at the White House with full access to President F.D. Roosevelt. One conversation reported by Vannevar Bush illustrates the turning point of the changed attitude towards Science in Peace times.

Vannevar Bush said,

"Roosevelt called me into his office and said, 'What is going to happen to science after the war?' I said, 'It's going to fall flat on its face.' He said, 'What are we going to do about it?' And I told him, 'We better do something damn quick." 6

Soon after, President Roosevelt sent Vannevar Bush a letter asking him to address four questions.

- The first question dealt with "spinoffs": how to promote civilian innovations that arise from military research.

- The second question asked how to support medical research or the "war of science against disease."

\footnotetext{
${ }^{6}$ Bush, Vannevar, "Science - The Endless Frontier: A Report to the President on a Program for Post-War Scientific Research (Washington, DC: National Science Foundation, 1980)
} 
- The third question asked what the government could do then and in the future to aid research activities by public and private institutions - a complex and profound question which remains a subject of debate five decades later.

- The fourth question was how government could aid the task of "discovering and developing scientific talent in American youth."

President Roosevelt died before Vannevar Bush could finish his report. President Truman followed up but with less energy and vision. The creation of the National Science Foundation (NSF) was recommended by Bush in 1945 but it was created five years later under the impetus of another war - the Korean conflict. The second boost came in 1957 after the launch of the Russian Sputnik and four years later the American desire to "land a man on the moon." Conflict and National Insecurity have been necessary for energising the application of science to the problems of war and peace. It need not continue this way in this millennium - at least, for Pakistan.

The second, third and fourth questions of President Roosevelt are therefore, highly relevant for today's Pakistan - both for ensuring national security and for solving the great problems of peace, i.e. socio-economic development to provide:

- The means for human survival - food, water, shelter, education;

- Physical security from the threats of humanity and nature;

- Social security and stability in human relationships; and

- Human capacity for sustaining the above.

\section{Technological Innovation and Economic Growth}

Scientific knowledge provides economic value when it solves problems or is incorporated in technology and products. Defense, environmental protection, health provision, transport, energy systems - all require national infrastructures which link science with technology and, through that, with satisfaction of societal needs. Improving the quality of human life through improved preventive and therapeutic medicine requires knowledge in a wide range of scientific disciplines - genetics, chemistry, biology, materials sciences, statistics, mathematics, computer science, physics, nuclear medicine. National security also requires the whole spectrum of scientific disciplines from computer modeling for simulation of strategic scenarios to materials science, aerodynamics, robotics, quantum mechanics and nuclear physics. Environmental protection is becoming a life preserving necessity as we continue to impose an unsustainable burden on our ecosystem from the watersheds in the north to the seashores in the south, and 
the air/water environments in Pakistan's major cities. The science and technology needed to measure, monitor and mitigate these effects span a wide range of disciplines - atmosphere and climate sciences, physics and chemistry of the environment, clean combustion technologies, mathematics, computer science, molecular biology and so on. Figure 5 presents a subset of the range of science and technology needed for three important buman needs of Pakistan (or the developing world) - national security, environment and energy, and human bealth.

Figure 5: Sciences and Technologies for National Challenges

\begin{tabular}{lll}
\hline National Challenges & Science (examples) & Technology (Illustrative) \\
\hline National Security & Physics & Nuclear Technology \\
& Materials Sciences & Plasma Technology \\
& Computer Science & Materials Technology \\
& Robotics & Electronics \\
& Quantum Mechanics & Computing \\
& Chemistry & \\
& Mathematics & \\
\hline Energy \& Environment & Physics & Recycling \\
& Chemistry & Clean Combustion \\
& Biology & Sensoring \& Measurement \\
& Atmospheric \& & Waste Management \\
& Climate Sciences & \\
& Ecosystem & Information Management \\
& Electrical Engineering & Bio-remediation \\
& Mathematics & \\
\hline Human Health & Biochemistry, Biology & Information Management \\
& Genetics & Gene Sequencing \\
& Materials Sciences & Molecular Detection \\
& Nuclear Medicine & Clinical Evaluation \\
& Physics, Chemistry & Electronics \\
& Molecular Bioogy & Drug Design \\
& Mathematics & Measurement of Effects \\
\hline
\end{tabular}

Source: Adapted from: "Global Innovation/National Competitiveness," by Brown, Harold and Charles Herzfeld. A Report by the Center for Strategic and International Studies (1996), USA.

Historically, technological innovation has been the critical variable in explaining sustainable economic growth. Many studies have demonstrated that social returns from research and development (R\&D) expenditures are 
about $50 \%$ per annum. One recent review $^{7}$ of econometric evidence concluded that the average private annual rate of return to innovation seems to be between 20 and $30 \%$, while the social rate of return is closer to $50 \%$ (Figure 6). Similar estimates of social returns have been made for public sector expenditures on R\&D. The World Bank's Consultative Group on International Agricultural Research (CGIAR) and its predecessors generated social returns in excess of $100 \%$. The Green Revolution (Rice \& Wheat) came from investments in R\&D by IRRI and CYMMIT and saved the world from famine. Similar gains have been observed when publicly funded R\&D, effectively managed, lifted millions out of food and income poverty.

Figure 6: Private \& Social Rates of Returns to Private R\&D

\begin{tabular}{lcc}
\hline & Estimated Rate of Returns (\%) \\
\hline Author & Private & Social \\
\hline Naduri (1993) & 25 & 50 \\
Mansfield (1997) & 25 & 56 \\
Terlecky (1974) & 29 & $48-78$ \\
Sveikanskas (1981) & 25 & 50 \\
Goto-Suzuki (1989) & 26 & 80 \\
Bernstein-Nadiri (1988) & 27 & 100 \\
Scherer (1982) & 35 & 125 \\
\hline
\end{tabular}

Source: White House, Council of Economic Advisors, "Supporting Research and Development to Promote Economic Growth: The Federal Government Role," October 1995.

The high private returns play an important role in the global marketplace where a world-class science and technology infrastructure is seen as a national asset and attracts investment capital out of the globally available capital stream. Proximity to such an infrastructure provides competitive advantage to companies.

Globalisation offers a wealth of opportunities to Pakistan. These opportunities will pass us by if we are not ready as a nation to utilise them. The "capacity to innovate" is the ultimate source of national productivity. All nations are competing on the same playing field and as the Center for Strategic and International Studies (CSIS) Report on Innovation and Competitiveness concluded, a scientific infrastructure is necessary to create the national capacity to innovate. It recommended a national strategy for the USA - a country which is millions of miles ahead of Pakistan in terms of having a

\footnotetext{
${ }^{7}$ White House Council of Economic Advisors - "Supporting Research and Development to Promote Economic Growth: The Federal Government's Role” October 1995.
} 
140 The Lahore Journal of Economics, Vol.7, No.1

dynamic science and technology infrastructure. If the USA needs a strategy, then Pakistan certainly needs one; but more importantly, its effective implementation. This means that science has to be properly integrated into the social and economic fabric of society to create the "national capacity to innovate." This "capacity" is fundamental to Pakistan's sustained economic revival and thus for enabling it to address the acute security and poverty reduction challenges that it is facing. Some US estimates ascribe to innovation more than half of the long-term rate of increase in US GNP. A similar level of contribution to Pakistan's GNP, if we can achieve it, would double its growth rate. The "capacity to innovate" comes from the infrastructure which connects scientists, technologists, industry, academia and government, and integrates this diversity into an organic whole. Such an asset/infrastructure does not replicate easily and so is relatively immobile across national boundaries. Global capital is likely to come to the nation which has such an asset/infrastructure. It is not by accident that global capital flows to Silicon Valley, Bangalore, Boston, Virginia, Singapore and China but not to Pakistan or Sri Lanka. The integration requires a complex managerial undertaking at the Pakistan level:

- A policy environment that fosters and rewards innovation (Compensation; scientific values)

- Ample support from the government for a science and technology infrastructure (Financing the science infrastructure)

- A national education system which produces competent scientific and engineering capacity as well as imparts scientific "values" (Financing; scientific values)

- Collaboration networks that link R\&D performers and users (Infrastructure; scientific values)

- An open trading system which promotes two-way flow of capital and talent (International links to $R \& D$ )

Does Pakistan have such a S\&T infrastructure? The appropriate scientific values? The scientific capacity? It does not.

\section{Pakistan's Scientific and Managerial Capability}

Pakistan's scientists/engineers population is about 480,000 . Of those, only 14,000, or less than 3\% of the total, are engaged in research and development $(R \& D)$. This translates to 96 scientists/engineers per million 
people. In comparison, India has 300, Korea 2,600, USA 3,750 and Japan 6,300 . That is, Japan's scientific and engineering capability, normalised by population size, is about 60 times that of Pakistan, and Korea's is thirty-fold higher. Pakistan has only 2,500 $\mathrm{Ph}$. Ds working in science and technology and, of these, only 170 are active in scientific work. About $60 \%$ of these active scientists are retiring in two to three years and no replenishment of this capacity is taking place (Figures 7, 8).

Figure 7: Comparative Scientific and Creative Capability

\begin{tabular}{|c|c|c|c|c|c|}
\hline & $\begin{array}{l}\text { Scientists \& } \\
\text { Engineers in } \\
\text { R\&D per } \\
\text { million people } \\
(1995)\end{array}$ & $\begin{array}{l}\text { High } \\
\text { Technology } \\
\text { Exports as \% of } \\
\text { Manufacturing } \\
\text { Exports (1997) }\end{array}$ & $\begin{array}{l}\text { Average } \\
\text { Annual } \\
\text { Growth of } \\
\text { exports in } \\
\text { f Goods \& } \\
\text { Services } \\
(1990-1998)\end{array}$ & \multicolumn{2}{|c|}{$\begin{array}{l}\text { Number of patent } \\
\text { applications filed in } 1996\end{array}$} \\
\hline \multicolumn{2}{|l|}{ Country } & & & Residents & $\begin{array}{l}\text { Non- } \\
\text { Residents }\end{array}$ \\
\hline China & 537 & 21 & 14.9 & 11,698 & 41,016 \\
\hline India & 300 & 11 & 12.4 & 1,660 & 6,632 \\
\hline Indonesia & 180 & 20 & 8.6 & 40 & 3,957 \\
\hline Korea & 2,640 & 39 & 15.7 & 68,446 & 45,548 \\
\hline Malaysia & 85 & 67 & 13.2 & 141 & 3,911 \\
\hline Pakistan & 96 & 4 & 3.2 & 16 & 782 \\
\hline USA & 3,730 & 44 & 8.1 & 111,883 & 111,536 \\
\hline Japan & 6,310 & 38 & 3.9 & 340,861 & 60,390 \\
\hline
\end{tabular}

Source: World Bank 1998/99 World Development Report, World Intellectual Property Organization (1998/99). 
142 The Lahore Journal of Economics, Vol.7, No.1

Figure 8: Pakistan - Science and Technology (S\&T) Capacity

Total number of high level S\&T manpower (1995)

480,000

S\&T human resource base as \% of total population

$0.4 \%$

S\&T Ph.Ds (1998)

2,486

$\mathrm{S} \& \mathrm{~T} \mathrm{Ph} . \mathrm{Ds}$ as \% of total S\&T manpower

$0.52 \%$

Total S\&T faculty in Pakistan's 37 universities

4,400

$75 \%$ of the $\mathrm{Ph} . \mathrm{Ds}$ are in five fields:

$\begin{array}{rr}\text { Agriculture } & 648 \\ \text { Chemistry } & 501 \\ \text { Biology } & 373 \\ \text { Physics } & 227 \\ \text { Mathematics } & 110\end{array}$

R\&D scientists \& engineers per million population

$\%$ of GNP spent on R\&D

$0.2 \%$

Per capita R\&D expenditure (1998)

$\begin{aligned} \text { Pakistan } & \text { US\$0.65 } \\ \text { India } & \text { US } \$ 2.40 \\ \text { China } & \text { US\$2.90 } \\ \text { Korea } & \text { US\$285 } \\ \text { Japan } & \text { US\$595 }\end{aligned}$

Pakistan's R\&D not integrated with production

Share of Pakistan in the world's mainstream journals

$0.063 \%$

Source: $\quad$ Science \& Technology Indicators for Pakistan - Pakistan Council for Science \& Technology, Pakistan, 1999.

The above was a quantitative measure of scientific capability. For making a "quality of capability" estimate, we could use the "number of scientific journal articles published" or "number of patent applications" as proxy. Pakistan's share of "mainstream science journal articles" was $0.06 \%$. This rate is one-fourth of Turkey's; one-tenth of Brazil's; one-thirtieth of India's (see Figure 9). Pakistan's rate of patent applications was 800 in 1996 compared to 8,000 for India and over 100,000 for Korea. Figure 10 illustrates the exponential growth in scientific publications since the Industrial Revolution - Pakistan is neither participating as a contributor nor as a beneficiary of this exponentially growing river of R\&D knowledge. This comparative information indicates the extent of the "quantitative" and 
"qualitative" effort that Pakistan has to make to join the ranks of those who have succeeded in the $20^{\text {th }}$ and are likely to retain that lead in the $21^{\text {st }}$ century.

Figure 9: Share of Mainstream Science Journals

\begin{tabular}{lc}
\hline \multicolumn{2}{c}{ Articles (\% of total for all nations) (1994) } \\
\hline Country & \% of Total \\
\hline US & 30.817 \\
Japan & 8.244 \\
UK & 7.924 \\
Germany & 7.184 \\
France & 5.653 \\
Canada & 4.302 \\
Russia & 4.092 \\
India & 1.643 \\
China & 1.339 \\
Brazil & 0.646 \\
S. Korea & 0.546 \\
Egypt & 0.28 \\
Turkey & 0.243 \\
Saudi Arabia & 0.129 \\
Pakistan & $\mathbf{0 . 0 6 3}$ \\
Yemen & 0.008 \\
\hline
\end{tabular}

Source: Science Citation Index, 1994 
Figure 10: Growth of Scientific Journals: The scientific enterprise has grown exponentially over the three centuries following the Industrial Revolution.

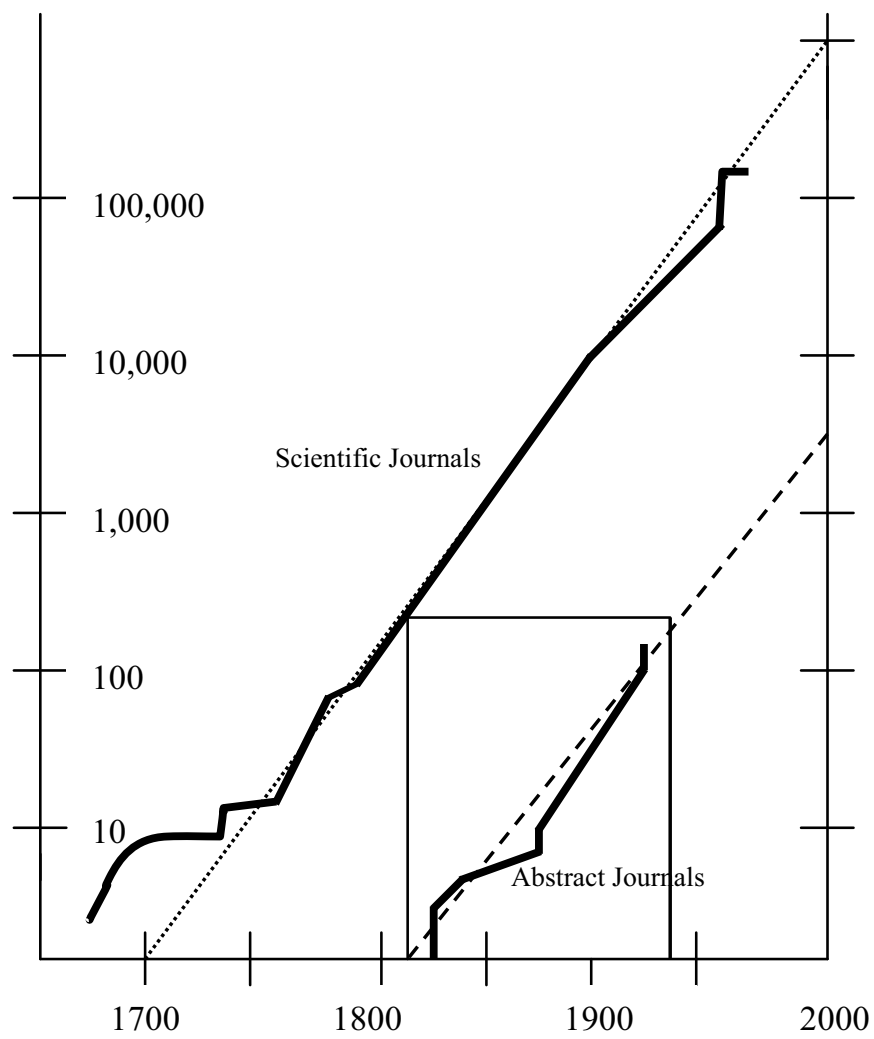

Source: Science and Technology in World History by McClellan III \& Harold Dorn, p 361 John Hopkins Press, 1999.

The lesson from the above is that the science-content of all products and processes is increasing in the developed and emerging economies. The more science a new product or process has, the more it is likely to be competitive in the global market place. Ninety percent of the world research capability is concentrated in about 35 countries with about $25 \%$ of world population. The R\&D expenditures in these countries range from $2.3 \%$ of GNP (U.K.) to $3.1 \%$ of GNP (Japan). The US spends $2.7 \%$ on R\&D. Figure 12 presents a time series picture of R\&D and its recent sectoral distribution in the US. 
Figure 11: The level of US government support for science and scientific research has risen dramatically since the 1940s, both in terms of the number of dollars and relative to the overall federal budget.

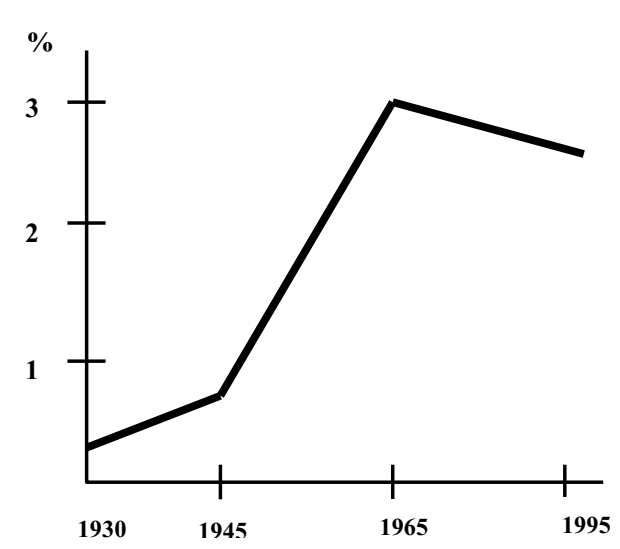

$\%$ of GNP/GDP

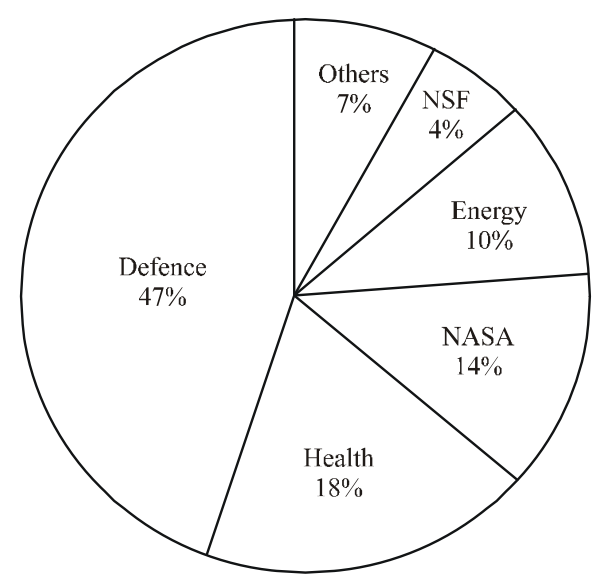

FY 1997

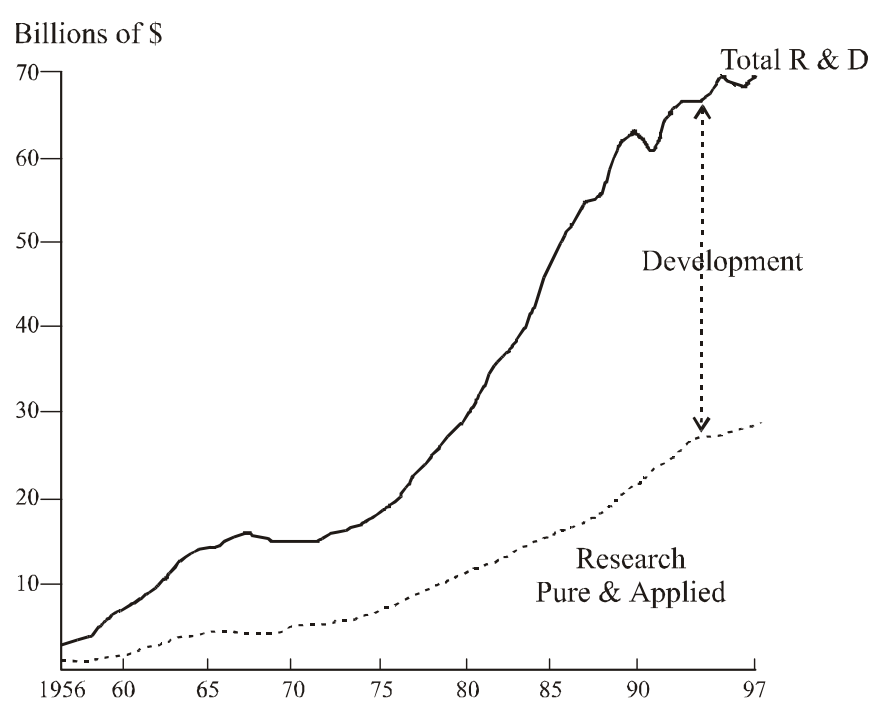

Source: $\quad$ Science \& Technology in World History by McClellan III, James-E \& Harold Dorn, John Hopkins Press, 1999

In comparison, Pakistan spends about $0.2 \%$ (Figure 8), hence the imperative necessity for Pakistan to design an effective strategy to rapidly bring about an increase in its domestic scientific capability on which to seek 
146 The Lahore Journal of Economics, Vol.7, No.1

sustainable development. Without such an increase in its domestic scientific capability Pakistan will continue to be technologically, and hence economically and politically, dependent. This is lucidly illustrated in the two vicious circles of Technological and Economic Dependence (Figures $2 \& 3$ ).

The conclusion is that Pakistan needs to take a crash approach to the creation of a functioning domestic scientific community to act as an intelligent conduit from the international scientific community to the domestic producers. The absorption by the domestic scientific community will include sifting ideas for relevance and transformation of these ideas in conjunction with the domestic engineering community into appropriate technology for national development of agriculture, industry, services and exports. The reverse flow of problems from the producers to the scientific community would complete the feedback loop and keep this network of functions dynamically relevant. The creation and maintenance of a domestic scientific community will require a responsive education system which produces the needed technical skills as well as the creativity which facilitates innovation and thus economic growth.

\section{Scientific Infrastructure and Scientific Values}

In order to successfully compete in the next millennium, Pakistan has to introduce a world class level of science and mathematical ${ }^{8}$ education (Figure 12) in the schools and universities of Pakistan. It will not be possible to become a high-income society without an educated and scientifically literate population. Of course, scientific or general literacy by themselves cannot guarantee transition of Pakistan's economy to higher levels of income and development. A collective national will is also needed to ensure availability of the enabling environment, i.e. science infrastructure and scientific values. This enabling environment will not be created overnight. Thus, we must begin now to create the needed infrastructure and to acquire and practise scientific values - which are similar to Islamic values. To illustrate this congruence let me share with you a brief review ${ }^{9}$ of the role that science and scientific values have played in creating and sustaining the Islamic civilization.

\footnotetext{
${ }^{8}$ It is revealing to observe that in a proficiency test in mathematics and science of 13 year olds, East Asian countries ranked in the top three. USA was fifteenth. Pakistan was not on the screen.

${ }^{9}$ From Ayub Omayya: The Rise and Decline of Science in Islam (1998).
} 
Figure 12: Proficiency Test Scores in Mathematics and Science for 13 years old pupils (1991)

\begin{tabular}{lccc}
\hline Country & $\begin{array}{c}\text { Average days' } \\
\text { instruction per } \\
\text { year }\end{array}$ & $\begin{array}{c}\text { Mathematics \% } \\
\text { correct }\end{array}$ & $\begin{array}{c}\text { Science \% } \\
\text { correct }\end{array}$ \\
\hline China & 251 & 80 & 67 \\
Korea & 222 & 73 & 78 \\
Taiwan & 222 & 73 & 76 \\
France & 174 & 64 & 69 \\
Italy & 204 & 64 & 70 \\
Canada & 188 & 62 & 69 \\
England & 192 & 61 & 69 \\
USA & 178 & 55 & 67 \\
\hline
\end{tabular}

Source: International Council of Scientific Unions (ICSU) in 'ICSUS' Role in International Science

The period 750 A.D. to 1100 A.D. has been described by Dr. Abdus Salam as the Golden Age of Science in Islam: it was in this period that the foundations of the experimental method were laid for humankind. Ibn-alHaitham was a great Muslim physicist. In his work on optics he anticipated Fermat's Principle of Least Time by many centuries. Roger Bacon's opus majus Part V is essentially a copy of Ibn-al-Haitham's optics. It is pertinent to note Bacon's remark to his contemporaries that he "never wearied of declaring that a knowledge of Arabic and Arabic science was the only way to true knowledge."

Within a century or so after al-Biruni, Ibn-al-Haitham, Ibn-Sina, first class science petered out in the Islamic world. The world went into the dark ages from which it began to get revived five centuries later by the famous names of modern science: Galileo, Copernicus, Newton. Why did science in the Islamic civilization die? Dr. Abdus Salam explained the decline in terms of increasing lack of tolerance for innovation, and isolation in the sciences. Lack of tolerance for innovation began to develop from the $12^{\text {th }}$ century onward. This process led to a loss of scientific values and produced "isolation of the sciences." A lucid example of apathy toward innovation is a quotation from Ibn Khaldun at the end of the $14^{\text {th }}$ century:

"We have heard that on the northern shores of the Mediterranean, there is a great cultivation of philosophical sciences. They are said to be studied there again, and to be taught in numerous classes. 
Existing systematic expositions of them are said to be comprehensive, the people who know them numerous, and the students of them very many... Allah knows better what exists there... But it is clear that the problems of physics are of no importance for us in our religious affairs. Therefore, we must leave them alone."

Bronowski defines sciences as "the organization of our knowledge in such a way that it commands more of the hidden potential in nature." Thus the "values" science promotes are: rationality, creativity, the search for truth, openness, tolerance for disagreement, respect for evidence, and for dialogue. These scientific values are identical to the core values of Islam, i.e. tolerance, dialogue, search for truth, honesty and fairness. As we have seen in the brief historical review of Islamic civilizations the non-practice of these values had strongly contributed to their decline. This convergence of the "values" of science and Islam thus, is an additional reason for Pakistan to promote science as a core instrument in the development process. This will force us to protect independence of inquiry through legal and moral safeguards. Free speech, free thought, tolerance, arbitration through evidence are all values worth promoting and defending for a "good society," not just for "good science."

\section{Recommendations}

The Government has the primary responsibility in creating the scientific infrastructure and maintaining a climate where scientific values can be practised. But the domestic scientific community has an equal, if not greater, responsibility to demand the infrastructure and promote, protect, and practise scientific values. In the process of building the infrastructure we must not forget that Pakistan has a diaspora which has immediately tappable scientific capacity. These scientists may live abroad, but in the first generation, remain culturally tied to Pakistan. Most of them retain a strong sense of responsibility for fellow citizens back home. All scientific talent that we can tap for the short or long term will have to be mobilised. Further we should also remember the basic universality of science. The intrinsic nature of science is universal, its success depends on cooperation, interaction and exchange, much of which goes beyond national boundaries. The community of scientists is international, the population of Pakistani Scientists in the diaspora should be considered part of the community and not as aliens. This is a long journey but it is a necessary one for our sustainability.

The Government under the leadership of the Minister of Science and Technology has begun this journey. But the crisis in science needs prior attention over our economic crisis because the former is a solution to the 
latter. Awareness of this crisis in science and the role science can play to ameliorate the economic crisis is, however, not sufficiently widespread in the government and society. This must change. Five actions comprise the process through which awareness levels can be raised and adequate implementation processes initiated.

- Creation of a domestic scientific community which has adequate scientific expertise to be able to absorb and adopt imported technology.

- Develop science-based technology for the future.

- Action: Try to reach one quarter of the current Korean level of scientists/engineers per million people, i.e. from the present level of 100 to 500 per million people, in ten years from now.

- Re-orientation of science and mathematics education from primary to university levels to make it relevant for the needs of the $21^{\text {st }}$ century.

Action: To begin now and complete in five years from now.

- Re-appraisal and expansion of current $R \& D$ programmes in universities, R\&D agencies, and industry to accomplish the first two objectives above.

Action: To increase R\&D expenditures from $0.2 \%$ of $G N P$ to $1 \%$ by ten years from now.

- Create institutional mechanisms to increase interaction between industry, policy makers and the domestic scientific community.

Action: Begin within the next six months and continue.

These are ambitious targets but achievable if there is national will. The monetary cost of accomplishing this may appear high but the returns are higher - recall that social rates of return from effective R\&D exceed $50 \%$. Also, the cost of not doing what is needed to accomplish the above or similar targets will be unacceptably high, i.e. continuance of poverty for millions and continuing dependence on other nations.

Let me close by quoting Dr. Abdus Salam on the necessity and importance of a "meaningful commitment towards science."

"By and large, there has been scant realization in the South that science can be applied to development as, for example, there was at 
150 The Lahore Journal of Economics, Vol.7, No.1

the time of the Meiji Restoraton around 1870 when Japan's emperor took five Oaths. One of the oaths set out a National Policy toward science: 'Knowledge will be sought and acquired from any source with all means at our disposal for the greatness and security of Japan.'

For the South the consequences of this lack of commitment to science have been - few research centers for applied sciences, subcritical and isolated communities of scientists (with scant provision for infrastructure, for scientific literature and international contacts), weakness in scientific education and little expenditure on R\&D."

This describes current Pakistan quite accurately - but we must change this through the above actions and a collective national will. 


\section{References}

Abdus Salam, "Notes on Science, Technology and Science Education in the Development of South." Published by the Third World Academy of Sciences for the $5^{\text {th }}$ meeting of the South Commission, 1989.

Ayub K. Omaya, "The Rise and Decline of Science in Islam," A1 Razi Lecture at the Islamic Medical Association of North America, July 1988.

M. A. Kazi, "The Need for Integrated S\&T policies for Islamic Countries: The Role of Comstech" in Essays on Science in honour of Dr. M.A. Kazi. Edited by Hakim Mohammad Said, Baital-Hikmah.

Beranek, W; Ranis, G (Editors), 1978, Science, Technology and Economic Development - A Historic and Comparative Study. Praeger Publisher.

Cardwe11, D.S.L., Science, Technology and Economic Development - The British Experience, Chapter 2. (Beranek, op.cit.)

Hoodbhoy, P. (Editor), 1998, Education and the State - Fifty Years of Pakistan. Oxford University Press.

Tahir, Pervez, 1980, Economic and Social Thinking of Quaid-e Azam, Research Society of Pakistan, University of Punjab.

Jali1, Nasir, "Pakistan’s Education - The First Decade," (Hoodbhoy, op.cit.)

Sen, Amartya, 1999, Development as Freedom. Alfred K. Knopf Publishers.

Husain, Tariq, "Pakistan - Role of Education for a Sustainable Future," Zahid Husain Memorial Lecture Number 12, 1996. State Bank of Pakistan.

Evenson, R.E. Singh, L., "Economic Growth, International Technological Spillovers and Public Policy: Theory and Empirical Evidence from Asia”, 1997. Yale Growth Center Discussion Paper 777. Yale University. 